\title{
Intestinal Hemorrhage
}

National Cancer Institute

\section{Source}

National Cancer Institute. Intestinal Hemorrhage. NCI Thesaurus. Code C54581.

Bleeding originating in the gastrointestinal tract. 